\title{
Comparative analysis of the innovative activity of peripheral regions of Russia and Germany
}

\author{
H.-Christian Brauweiler \\ Westsächsische Hochschule Zwickau \\ (University of Applied Sciences) \\ Faculty of Economics and Business \\ Zwickau, Germany \\ christian.brauweiler@fh-zwickau.de
}

\author{
Larisa Vladimirovna Ponomareva \\ Volgograd State University, \\ Institute of Management and Regional Economics, \\ Volgograd, Russia \\ larisa.ponomareva@ volsu.ru
}

\author{
Andrey Vasilievich Shevandrin \\ Volgograd State University, \\ Institute of Management and Regional Economics, \\ Volgograd, Russia \\ shevandrin@volsu.ru
}

\begin{abstract}
The article analyses the innovative activity in peripheral regions of Russia and Germany. The comparison of the dynamics of the innovative activity in the regions under analysis is made on the basis of the development and grouping of relevant indices. The criteria of absolute and relative innovative activity are studied. The relationship between the innovative potential of a region and the innovative activity is determined. The factors influencing the changes in the innovative activity are given. The degree to which the changes in the level of the innovative activity between agglomeration centers having a high concentration of industrial enterprises and peripheral areas differ is studied. The analysis of the analysis identifies the reasons for low innovation in Russia: insufficient financing of innovation activity, low level of competition in the regions, lack of motivation for innovative activity among managers of enterprises, etc.
\end{abstract}

Keywords - region, peripheral region, innovations, innovative activity, level of innovative activity, absolute innovations, relative innovations, innovative policy, innovation costs

\section{INTRODUCTION}

A high innovative activity of the economic subjects today is an important factor of the provision of the competitiveness of the national business under the conditions of a global competition. The opportunity of comparison of the level of the innovative activity with similar indices of enterprises from other countries has considerable importance for Russian entrepreneurs. The globalization of the world economy leads to the intensification of the competitive fight in the national and foreign markets and under these conditions it is important to achieve a high level of the innovative activity comparable with the leading countries of the world by Russian enterprises and regions.
Today the systems of the comparative analysis and the assessment of the countries according to the level of the innovative activity are being actively developed. It is worth mentioning here the Oslo methodology and also the calculation of the annual global innovative index. However today there is no necessary number of papers which would contain the study of the innovative activity with similar regions of other countries.

In this respect the comparative analysis of the level of the innovative activity of such regions like the Volgograd region and the Free State of Saxony in Germany has a particular importance. Despite a considerable difference between these regions and the countries of Russia and Germany in the whole there is also some similarity between them. Firstly, both regions have moved from the planned economy to the market one. Secondly, these regions are located in the South of the countries under analysis and they are border regions which can be seen as peripheral regions in particular. Thirdly, they have a comparable industrial structure and measurable general parameters of the regional development.

\section{METHODOLOGY OF THE ANALYSIS OF THE LEVEL OF THE INNOVATIVE ACTIVITY OF PERIPHERAL REGIONS OF GERMANY AND RUSSIA}

Today there exists a system of statistical indices which characterize the level of the innovative activity of the economic actors in a region. Also as it was mentioned above at the present stage of the economic development for the determination of the level of the economic activity of a territory, different rankings of regions are used. The rankings of the innovative activity can be generally subdivided into two groups in respect of the territory size: national ratings and global ones. For the comparison of the regions of different 
countries the indices in the system of global ratings are employed. The basic global ratings are Global Innovation Index and Bloomberg Innovation Index.

According to the mentioned ratings Russia and Germany have different positions (table 1).

TABLE I. RANKS OF RUSSIA AND GERMANY IN GLOBAL RATINGS IN 2016

\begin{tabular}{|c|c|c|}
\hline \multirow{2}{*}{ Название рейтинга } & \multicolumn{2}{|c|}{ Страны } \\
\hline & Германия & Россия \\
\hline Global Innovation Index & 10 & 43 \\
\hline $\begin{array}{l}\text { Bloomberg Innovation } \\
\text { Index }\end{array}$ & 2 & 12 \\
\hline
\end{tabular}

However as it was mentioned it is hard to apply the methodology under consideration to the comparative assessment of some regions of different countries.

Firstly, a large number of indices for comparison is not always necessary to compare different regions and industries.

Secondly, as it was mentioned, a global innovation index takes into consideration both potential and results of the innovative activity. In this case the innovative activity reflects only the efficiency. In this respect not all the indices dealing with the innovative potential can be relevant for the assessment of the innovative activity. Thirdly, not all the indices are reflected in a way in the system of the statistical reporting of the analyzed countries and are relevant from the point of their value.

In respect to these relevant indices that can be used for the comparison of the level of the innovative activity of two regions of the countries under analysis, the following ratios can be taken into account:

- ratio of the personnel number employed in the Research and Development to the total number of the employed;

- ratio of the costs for Research and Development in Gross regional product;

- share of education in Gross regional product;

- internal costs for Research and Development;

- number of the students per 10.000 of regional population;

- share of the incoming patent applications;

- share of the innovative active enterprises in the total number of enterprises;

- share of budgetary funds in the internal costs for Research and Development;

- share of higher education institutions in the internal costs for Research and Development;

- share of extrabudgetary funds in the internal costs for Research and Development.

The choice of these indices is determined by the fact that they allow making a comprehensive assessment from the point of view of the development of the human capital, innovative infrastructure, share of the innovative production, share of the technology intensive and science driven industries in the gross regional product. These indices are relative ones and give the opportunity to compare the analyzed countries without taking into account the basic inequality in the volumes of the industrial production, volume of the gross regional product and so on. The mentioned indices are accessible in the system of the statistical reporting both in Germany and in Russia.

An important part of the analysis of the problem of the comparative study of the level of the innovative activity in the regions of Russia and Germany is the calculation of the difference of absolute and relative innovations [1]. The absolute innovations are those which have been developed for the first time and have been introduced within the given enterprise or a region. The relative innovations are those which have been introduced and developed in other countries and regions. Herewith the more widespread is the innovation and the longer it is used, the higher degree is its relativity. It stands to reason that the degree of the absoluteness of the innovations influences the competitive environment of an enterprise and a region. The comparison of such indices for Russia and Germany is especially important as here we can find a considerable difference in the degree of the relativity of the innovations used for the first time. Also the general integrated index of the innovation activity mentioned above can be considerably adjusted taking into consideration the relativity of innovations.

As in every enterprise both relative and absolute innovations are used, it is important to assess their real percentage in the structure of innovations. If the innovations are analyzed according to their basic types (product, technological, processing, marketing and so on), the index of the degree of the relativity can be presented as a summary relation of absolute and relative innovations in respect of their types.

$$
\mathrm{Q}=\sum \mathrm{R}_{1} / \sum \mathrm{R}_{2}
$$

here, R1, - absolute innovations according to types; R2, relative innovations according to types.

The correlation of these indices allows final grouping of the transactor units according to the level of their innovation activity taking into account the criterion of the relativity of the innovations: $\mathrm{Q} \geq 1$ - high; $\mathrm{Q}=1$ - medium; $\mathrm{Q} \leq 1$ - low. Thus the higher is the share of the absolute innovations in monetary terms, the higher is the real level of the innovative activity. The latter coefficient allows taking into account the quality of innovations by contrast with the use of only quantitative statistical indices of the innovation activity which are presented in the official statistical reporting.

\section{RESULTS OF THE COMPARATIVE ANALYSIS OF THE LEVEL OF THE INNOVATIVE ACTIVITY IN THE REGIONS OF SAXONY (FREE \\ STATE) AND THE VOLGOGRAD REGION ON THE BASIS OF SEPARATE COEFFICIENTS}

It is worth mentioning that the Volgograd region traditionally is not among the leading regions from the point 
of view of the innovative development in comparison to other regions taking into account such parameters as science intensity, localization of the scientific potential, indices of the innovative and investment activity [2]. Nevertheless it has a comparatively high innovative potential which is determined primarily by a high concentration of educational, scientific and research institutions, industrial enterprises of highly technological industries (metallurgy, chemistry and petrochemistry, engeneering and others). All this creates favorable conditions for the development of the innovative activity in the region [3].

A considerably high level of the innovative activity has the Free State of Saxony what is determined by a high concentration of the industrial production in the territory of the federal state and in first turn by technology intensive industries such as machine construction, chemical industry, food production, automotive industry, especially computerrelated (silicon) industry and others and also by a high degree of the localization of scientific and research organizations, by the development of the innovative infrastructure.

In general the study of the innovative activity of regions according to the indices mentioned above can be presented in the following table 2 .

TABLE II. COMPARATIVE ANALYSIS OF THE INNOVATIVE ACTIVITY OF THE FREE STATE OF SAXONY AND THE VOLGOGRAD REGION IN 2015

\begin{tabular}{|c|c|c|c|}
\hline № & Index & Saxony & $\begin{array}{l}\text { Volgograd } \\
\text { region }\end{array}$ \\
\hline 1. & $\begin{array}{l}\text { Ratio of the personnel } \\
\text { number employed in the } \\
\text { Research and } \\
\text { Development to the total } \\
\text { number of the employed }\end{array}$ & $5,32 \%$ & $0,33 \%$ \\
\hline 2. & $\begin{array}{l}\text { Ratio of the costs for } \\
\text { Research and } \\
\text { Development in Gross } \\
\text { regional product }\end{array}$ & $2,73 \%$ & $0,43 \%$ \\
\hline 3. & $\begin{array}{c}\text { Share of education in } \\
\text { Gross regional product } \\
(2014)\end{array}$ & $4,9 \%$ & $3,5 \%$ \\
\hline 4. & $\begin{array}{l}\text { Internal costs for } \\
\text { Research and } \\
\text { Development }\end{array}$ & $3099 \mathrm{mln} . \underline{€}$ & $\begin{array}{c}3417,7 \mathrm{mln} . \\
\text { rubles }(50 \mathrm{mln} . \\
\underline{€}) \\
\end{array}$ \\
\hline 5. & $\begin{array}{c}\text { Number of the students } \\
\text { per } 10.000 \text { of regional } \\
\text { population }\end{array}$ & 277 & 242 \\
\hline 6. & $\begin{array}{l}\text { Share of the incoming } \\
\text { patent applications } \\
(2013)\end{array}$ & 966 & 268 \\
\hline 7. & $\begin{array}{c}\text { Share of budgetary funds } \\
\text { in the internal costs for } \\
\text { Research and } \\
\text { Development }\end{array}$ & $28,5 \%$ & $70,9 \%$ \\
\hline 8. & $\begin{array}{l}\text { Share of higher } \\
\text { education institutions in } \\
\text { the internal costs for } \\
\text { Research and } \\
\text { Development }\end{array}$ & $28,0 \%$ & $10,3 \%$ \\
\hline 9. & $\begin{array}{l}\text { Share of extrabudgetary } \\
\text { funds in the internal } \\
\text { costs for Research and } \\
\text { Development }\end{array}$ & $43,4 \%$ & $29,1 \%$ \\
\hline
\end{tabular}

Sources: (Innonatsionnaya Aktivnost', 2016; Statistika Federalnoy Zemli Saksoniya, 2017; The Federal Statistical Office of Germany, 2016; Statistischen Ämter des Bundes und der Länder, 2016).

As the analysis showed the indices of the level of the innovative activity in the Volgograd region are inferior to similar indices of Saxony and this fact proves the inadequate efficiency of the practical application of the scientific, technological and innovative potential of the Volgograd region for the present moment. There can be a big difference in the following indices: the number of innovation results received legal protection and the costs of Research and Development, especially in terms of the structure of their sources: in Saxony, the share of budget funds does not exceed $30 \%$, while in the Volgograd region the share of budget allocations is more than $70 \%[4,5,6]$.

At the same moment it is worth mentioning that the largest part of innovation costs in the Volgograd region falls on the industry and makes up $98 \%$ whereas other industries (agriculture, communications, retail trade) have a lower innovation activity [7].

In fact as the analysis of the contemporary state of the innovative activity shows, the largest part of the innovations introduced in the enterprises of Russia in recent years are relative ones, i.e. they are introduced in these enterprises for the first time. In particular up to $80 \%$ of the innovative activity of the enterprises of the Volgograd region is determined by the purchases of the new foreign equipment whose analogues are already used in other countries.

\section{CONCLUSION}

Summing up the results of the comparative analysis of the innovative activity of Russian and German regions it is worth mentioning that both the level of the innovative activity in Saxony is somewhat higher than in the Volgograd region according to indices under consideration. This situation is determined by objective conditions. Here we can speak about the presence of basic conditions typical for both regions: isolated location, regional and sectoral structure, quantity and quality of regional factors of production, demographic parameters (population density, qualification level), peculiarity of location. Saxony has a larger volume of industrial production and has a bigger number of the employed in the industry. The population here is two times bigger than in the Volgograd region and the population density is also two times higher than in the Volgograd region. In the German state the industrial concentration is four times higher and the localization of the organizations involved in $R \& D$ is 2,5 times higher.

Herewith there exist specific reasons for a low innovative activity of national enterprises. When analyzing the process of the reduction of the innovative activity in the Russian regions and in particular in the Volgograd region it is worth mentioning a number of specific reasons: 
- insufficient number of the investment resources of enterprises. Thus, about $98 \%$ innovation costs are generally equity capital of enterprises and whereas in contrast in foreign countries the largest part of capital funds are the government funds and venture funds;

- strong competitive pressure from the part of foreign producers in the domestic market;

- absence of a common program of the innovative development and no system of the support of innovation intensive enterprises at the governmental level;

- absence of interest from the part of new enterprise owners in the expansion and modernization of a production;

- absence of legal protection from the tyranny of officials and local authorities and also from the part of criminality (raider takeovers);

- poor innovative infrastructure and system of the information provision of the innovative activity.

Also taking into account the relativity of the innovations the gap between the indices of the innovation activity of the regions under analysis increases due to the reduction of own scientific research by Russian enterprises in peripheral regions. As for the differences in the level of the innovative activity between central and peripheral regions, Russia is characterized by a higher index. Thus the level of the innovative activity in central regions is higher than in peripheral ones. This fact is connected with the availability of qualified personnel in the metropolitan areas of Moscow and Saint Petersburg, sophistication of innovative infrastructure, high concentration of the agricultural production and scientific organizations as well as the enterprises making their own research. The difference in the level of the innovative activity between central and peripheral regions both in Russia and in Germany has similar reasons:

- in peripheral regions there is not enough qualified personnel;

- in peripheral regions prevail small and medium sized enterprises and they mainly deal with mass production and there is no own research and development activity in these firms;

- numerous enterprises in peripheral regions do not have sufficient capital for the development and that's why function using borrowed capital, external capital sources on the basis of franchising agreements and so on;

- enterprises in peripheral regions rarely find net forms of cooperation as they depend on external sources of R\&D and investments. They are organized mainly like small and medium sized firms without special R\&D departments for carrying out their own scientific research;

- in peripheral regions the infrastructure is poor both for the organization of the industrial cluster itself and for the development of the innovative [8].

At the same time the difference between central and peripheral regions from the point of the level of the innovative activity in Russia is higher than in Germany and this fact is determined by the monocentric model of the Russian economy plus the vast distances between cities and regions. And if the difference between central and peripheral regions of Russia and Germany is insignificant but the difference according to the same index between peripheral regions of two is considerable, sometimes it is two times higher.

Thus it is worth mentioning that the potential of the innovative development of peripheral regions of Russia is not fully realized today. At the same time the growth of the innovative activity of the leading regional enterprises is an important condition for the competitive growth of the national economy. In particular the introduction of the innovations contributes to the growth of the production efficiency, improvement of labour conditions, satisfaction of the demand for qualified production, environmental improvement and so on. However today we can see an insufficient level of the innovative activity of Russian enterprises. As it was mentioned the reasons for that are insufficient financing of the innovative activity, low level of competition in regions, absence of the motivation for the investment activity from the part of the managers of the enterprises and so on. In this respect in the nearest future it is necessary to take a number of measures concerning the increase of the innovative activity in the regions of Russia which should be directed on the development of the innovation infrastructure, personnel training for the innovative activity, improvement of the investment climate. And in considerable degree for the achievement of these goals the use of the experience of the innovative development of German regions, especially of Free State of Saxony can help.

\section{References}

[1] Kurchenkov V.V. The importance of the regions economic activity evaluation in Russia 2012-2016/ Kurchenkov V.V., Fetisova O.V., Orlova A.A., Gladkaya E.A. // Revista Galega de Economia - 2017 - N 26(3), - c.33-44

[2] Deynega V.G. Osobennosti formirovaniya regional'noi struktury natsional'noi innovatsionnoi sistemy [Peculiarities of the formation of the national innovative system]// Ekonomika razvitiya regiona: problemy, poiski, perspektivy: ezhegodnik [Economy of the regional development: problems, search, prospects. Yearly book]. Vol. 9. Volgograd: Izdatelstvo Volgu, 2008. pp. 273-289.

[3] Kraynov A.E. Innovatsionnaya aktivnost' kak faktor formirovaniya sistemy upravleniya predpriyatiem [Innovative activity as the factor of the formation of the system of the enterprise management]// Sovremennaya ekonomika: opyt, problemy i perspektivy razvitiya [Contemporary economy: experience, problems and prospects of development]. 2014. №3. pp. 77-81.

[4] Statistischen Amter des Bundes und der Lander URL: http://www.statistik-portal.de (date 10.01.2018)

[5] Innovatsionnaya aktivnost' organizatsii Volgogradskoi oblasti v 2014 godu, analiticheskii obzor [Innovative activity of organizations of the Volgograd region in 2015, analytical review]. Volgograd: Volggradstat, 2016. 38 p.

[6] Statistika federalnoy zemli Saksoniya [Statistics of Free State of Saxony] URL: https://www.statistik.sachsen.de/index.html (date 30.12.2017)

[7] The Federal Statistical Office of Germany. URL: https://www.destatis.de/EN/Homepage.html (date 21.12.2017)

[8] Brauweiler H.Ch. Innovationen im peripheren Raum. Eine Analyse am Beispiel der Granzraume Sud- und Ostsachsens / H.Ch.Brauweiler. Mit einem Geleit von Matthias Kramer. Wiesbaden: Dt.Univ.-Verlag, 2002. $141 \mathrm{p}$. 